\title{
IMPLEMENTATION OF INVESTMENT BASED SALES GROWTH (IBSG) ON ASSET IMPROVEMENT
}

\author{
Siti Puryandani ${ }^{*}$, Oktavian Yodha Utama ${ }^{2}$ \\ 1,2 STIE Bank BPD Jateng, Semarang, Central Java, Indonesia \\ e-mails: ${ }^{1}$ sitipuryandani@gmail.com; ${ }^{2}$ oktavyodha@gmail.com
}

Received October 2, 2020; accepted December 30, 2020; published January 29, 2021.

\begin{abstract}
Objective: The implementation of investment based sales growth (IBSG) on asset improvement of the food and beverages companies from 2017 to 2019 is discussed in this study. The IBSG variables measured by the tangible asset, company's growth, positioning, liquidity, sales performance, business risk, firm size, profitability, and tax of each company. Research Design \& Methods: The sample is chosen based on purposive sampling with the criteria, finally 21 companies are taken from 31 companies. The data were collected from the company's financial report and measured by using formula adopted from earlier research. Findings: Tangible assets positively influenced to the capital structure, The growth of the company resulted negatively influenced to the capital structure, positioning positively influenced to the capital structure, liquidity positively significant influenced to the capital structure, capital structure is not influenced by sales performance and business risk, firm size positively influenced to the capital structure, profitability positively significant influenced to the capital structure, tax positively significant influenced to the capital structure. Limitations \& Recommendations: the value of $\mathrm{R}$ square is low, to add more variables is recommended for future research. The number of samples is too small, to add more period in future research is recommended. Contribution \& Value Added: This result contributes for the financial literature, especially related to the companies listed in the food and beverages companies group. Practically, stakeholders can consider this result as additional information in deciding policy.
\end{abstract}

Keywords: investment based sales growth; capital structure; food; beverage companies.

JEL codes: M4, L25, L66

Article type: research paper

\section{INTRODUCTION}

The company's capital structure still provides many interesting gaps to be investigated. In line with the research conducted by Modigliani \& Miller (1958), the capital structure puzzle seems to be still unresolved (Al-Najjar and Hussainey, 2011). The capital structure owned by each business unit shows a specific debt and equity ratio (Baker \& Powell, 2009; Graham \& Harvey, 2001). However, there is no universal consensus regarding perfect debt and equity ratios in the financial operations of a company. Most companies have a large amount of investment in their capital structure, and limited access to long-term capital. Therefore, they tend to rely on their own capital, loans from friends and relatives, short-term bank credit, and trade credit to finance the working capital needed for the day to day operations of their business. Therefore, most of the company's assets are in the form of current assets, and current liabilities are one of the main sources of external finance (Garcia-Teruel \& Solano, 2007). Management of working capital in companies is very important to maintain business life. A stable cash flow is essential to maintaining a business, and adequate working capital will maximize profits; meanwhile, poor working capital management is one of the main reasons for business failure. This is recognized from previous studies conducted by Deloof (2003) in Belgium; Padachi (2006) in Mauritius; Lazaridis \& Tryfonidis (2006) in Greece; Garcia-Teruel \& Solano (2007), and Caballero et 
al., (2012) in Spain; Gill, Bigger, \& Mathur (2010) in the United States; Ding \& Guariglia (2013) in China; and Enqvist et al., (2014) in Finland.

The relationship between work structure management and company profitability has been carried out by several previous researchers who have focused on efforts to increase the company's profitability on inventory with optimal capital structure management, optimal accounts are receivable and debt, and the cash conversion cycle (Caballero et al., 2012; Deloof, 2003; Garcia-Teruel \& Solano, 2007; Gill et al., 2010; Lazaridis \& Tryfonidis., 2006; Padachi, 2006). In addition, other researchers have examined the relationship between working capital management and access to capital (Ding \& Guariglia., 2013), and the impact of working capital on profitability (Enqvist et al., 2014). The main finding that has been commonly identified is that the management of the capital structure has a significant impact on company profits.

The reason why food and beverages companies are chosen to be the object in this study because these companies whose products are often consumed by the consumer and can survive under any policy conditions so that no matter how bad the policies are made, the company's products are still bought by consumers. If these production activities stalled for some time, it will be considered as bad news for the company because the production process requires fast time, then the company must strengthen internal factors in order to grow and survive, the attempt to strengthen internal factor is to administer the capital structure properly. In summary, it can be concluded, this research is intended to identify or determine the implementation of investment based sales growth (IBSG) on the capital structure in a food and beverage company from 2017 to 2019 .

\section{LITERATURE REVIEW}

\section{Trade-off Theory}

Trade-off theory implies that managers will think in terms of trade-offs between tax savings and the cost of financial difficulties in deciding the capital structure. tax deduction through increasing debt ratio is usually done by companies with high profitability, it aims to increase debt and reduce tax cost. The costs and benefits of this debt will determine the optimal leverage ratio. Examples of associated leverage costs are taken into account in some empirical corporate financing and bankruptcy costs (Scott, 1977), agency costs (Jensen \& Meckling, 1976), and loss of shield taxes (DeAngelo \& Masulis, 1980).

\section{Pecking Order Theory}

The pecking order theory implies that internal sources of funding are preferred by many companies compared to external sources of funding, debt that is safe against debt that is risky as well the latter is common stock. The essence of this theory is that there are two types of external and internal capital. This theory explains why companies focus on debt in small amounts. this is not because the companies have a low target debt ratio, but they need low external funding. Companies that are less profitable will tend to use bigger debt for two reasons, namely; (1) internal funds are not sufficient, and (2) debt is the preferred external source. Hence, This theory creates a hierarchy of sources of funds, namely internal (retained earnings), and external (debt and shares) (Allen, 2000; Myers \& Majluf, 1984).

\section{Agency Theory}

Jensen \& Meckling (1976) implied that the use of debt financing can alleviate conflicts that may exist between shareholders and managers as executors of debt operationalization. According to this approach, the capital structure is structured to reduce conflicts between various interest groups. The conflict between shareholders and managers is the concept of free cash flow. There is a tendency for managers to hold resources so they have control over these resources. Debt can be seen as a way to reduce free cash flow agency conflicts. If the company uses debt, then the manager will be forced to remove cash from the company to pay interest. To make correct calculations regarding capital structure, companies need to use online accounting software such as journals. The journal summarizes all of your company's financial records into an accounting system that can be used to produce financial 
reports according to company needs anytime and anywhere. With cloud technology and a certified security system, journal will keep your financial data safe without fear of risking loss.

\section{Market Timing Theory}

This theory implies that the current capital structure is rely on the company's historical experience of being expensive or underpriced by investors, companies that have a high power of share price will issue more equity than debt. Previous researches that have been conducted by Al-Najjar \& Hussainey (2011); Booth et al., (2001); Harris \& Raviv (1991); Memon et al., (2015); Ruslim (2009); Titman \& Wessels (1988) used this theory in various economic conditions.

\section{Relationship of Tangible Assets to Capital Structure}

Ownership of the assets of a company is important for the company because when borrowing from creditors, ownership of the company's assets shows whether the company has a suitable asset composition for use as collateral for returning the debt. So, the higher of company's tangible assets, the higher of the company's ability to be able to guarantee its long-term debt, so that the company's capital structure will be more optimal. On the contrary, the lower of company's tangible assets indicates the lower of the company's ability to be able to guarantee its long-term debt so that the capital structure will not be optimal. This statement agreed with previous studies that have been done by Akinyomi \& A. Olagonju (2013); Ichwan (2015); Tijow (2018).

H1: Tangible assets positively influenced to the capital structure of food and beverages companies.

\section{Relationship of Company's Growth to Capital Structure}

A company that is able to manage resources to generate profits so can increase assets that already owned can be identified as company that has good asset growth. Companies with growing assets the big ones are the companies that perform well to make a profit. The higher of the company's profit, the easier opportunity of the company to obtain external capital from debt because the risk of default is small. This statement agreed with previous studies that have been done by Alipour et al., (2015); Chadha \& Sharma (2015); Saleem et al., (2013); Sari (2015).

$\mathrm{H} 2$ : Company's growth positively influenced to the capital structure of food and beverages companies.

\section{Relationship of Positioning to Capital Structure}

The positioning in this discussion explains how high the company's sales growth position compared to industrial sales growth. The higher of the company's sales growth position in similar industrial group, the easier opportunity of the company to fulfil external capital or come from long-term debt, this make the company's capital structure higher. This statement agreed with previous studies that have been done by Akinyomi \& A. Olagonju (2013); Ichwan (2015); Tijow (2018).

H3: Positioning positively influenced to the capital structure of food and beverages companies.

\section{Relationship of Liquidity to Capital Structure}

Liquidity positively influenced to the capital structure happens when the higher of the company'sliquidity is obtained, the higher of the capital structure fulfillment will be obtained as well. Liquidity positively influenced to the capital structure occurs where the higher of the liquidity of a company, the higher of the company's ability to pay its short-term debt. This happened because developing companies generally require large funds. If internal funds are not sufficient for the company's needs, the company will choose debt as its external funding source. This statement agreed with previous studies that have been done by Joni \& Lina (2010); Sabir \& Qaisar (2012); Sakti (2002).

H4: Liquidity positively influenced to the capital structure of food and beverages companies.

\section{Relationship of Sales Performance to Capital Structure}

An increase in the company's capital structure occurs when there is also an increase in the company's sales performance,High corporate profits are obtained from high levels of sales performance, and this 
reflects that companies with high sales performance tend to use more debt than companies with low sales growth rates. The higher the company's profit, the easier it is for the company to obtain external capital from debt because the risk of default is small. This statement agreed with previous studies that have been done by Alipour et al., (2015); Chadha \& Sharma (2015); Saleem et al., (2013); Sari, (2015).

H5: Sales performance positively influenced to the capital structure of food and beverages companies.

\section{Relationship of Business Risk to Capital Structure}

Business risk is the risk of a company's assets related to the use of debt to fulfill these assets. Business risk can increase if the company uses high debt to meet funding needs. Risks arise along with the emergence of borrowing costs made by the company. The greater of the company's cost that must be borne, the higher of the risk that will be faced by the company. Therefore, the higher the existing business risk, the more difficult it will be for the company to obtain debt to meet the company's capital. This statement agreed with previous studies that have been done by Indrajaya (2012); Prabansari \& Hadri (2005).

H6: Business risk negatively influenced to the capital structure of food and beverages companies.

\section{Relationship of Firm Size to Capital Structure}

Large companies will be easier to obtain capital in the capital market compared to small companies because this easy access means that large companies have greater flexibility because companies with larger size have greater confidence in obtaining sources of funds so that it will be easier to obtain them. credit from outside parties. This statement agreed with previous studies that have been done by Abdul (2007); Ariyanto (2002); Armelia (2016); Handayani (2011) which stated that company size positively influenced to the capital structure of food and beverages companies.

H7: Firm size positively influenced to the capital structure of food and beverages companies.

\section{Relationship of Profitability to Capital Structure}

The higher of the company's profitability, the greater of the retained earnings but it would be balanced with higher debt because the company's prospects are better considered. Profitability positively influenced to the capital structure, which can occur because companies that are expanding require a lot of funds to encourage an increase of the profits in the future. This statement agreed with previous studies that have been done by Dewi \& Sudiartha (2017); Handayani (2011); Puspawardhani (2011).

H8: Profitability positively influenced to the capital structure of food and beverages companies.

\section{Relationship of Tax to Capital Structure}

High tax rates make companies tend to prefer debt, because with debt, the amount of tax that the company must pay will be reduced. According to the trade-off theory, a company that has a high debt ratio makes the amount of money it must spend to pay its debt and interest. The statement indicates that high debt will be able to reduce the level of income and its tax, therefore the company will pay lower income taxes. This statement agreed with previous studies that have been done by Andelina (2015); Widati \& Nafisah (2017) which stated that tax positively influenced to the capital structure.

H9: Tax positively influenced to the capital structure of food and beverages companies.

\section{METHODS}

\section{Data and Sample Selection}

This research used secondary data which was obtained from the Indonesia Stock Exchange (IDX) website page, www.IDX.co.id. The study population was all companies listed in the food and beverage companies. The sample was taken according to purposive sampling with criteria as food and beverage company that published annual report data for the period 2017 to 2019, used Rupiah 
currency in the annual report, had information of all research's variables. The number of samples that meet the sampling criteria was 21 companies out of 31 companies.

\section{Operational Variables}

Research variables measured using formulas that have become theories and were often used in previous studies. Operational definitions of research variables can be seen in Table 1 below.

Table 1. Measurement Scale of Research Variables

\begin{tabular}{|c|c|c|}
\hline Variable & Definition & Measurement \\
\hline Tangible Assets & $\begin{array}{l}\text { It is an asset in which the physical asset will } \\
\text { be used for business facilities, such as land, } \\
\text { land is the property that is used for business } \\
\text { purposes. }\end{array}$ & Tangibilit $\mathrm{y}=\frac{\text { Tangible asset }}{\text { Total asset }}$ \\
\hline Company's Growth & $\begin{array}{l}\text { A company's growth is the company's } \\
\text { ability to increase its size. }\end{array}$ & Sales Growth $=\frac{\text { Sales }_{\mathrm{t}}-\text { Sales }_{\mathrm{t}-1}}{\text { Sales }_{\mathrm{t}-1}}$ \\
\hline Positioning & $\begin{array}{l}\text { The company's sales position to total } \\
\text { industry's sales }\end{array}$ & Positioning $=\frac{\text { Company's sales }}{\text { Industry's sales }}$ \\
\hline Liquidity & $\begin{array}{l}\text { The company's ability to pay its short-term } \\
\text { debt }\end{array}$ & Liquidity $=\frac{\text { Current asset }}{\text { Current liability }}$ \\
\hline Sales Performance & The annual change in year-end sales prices & Change in year-end sales prices \\
\hline Business Risk & The annual change in the company's EBIT & Annual change in the company's EBIT \\
\hline Firm Size & $\begin{array}{l}\text { A measure of the number of total assets } \\
\text { owned by the company }\end{array}$ & Natural Logarithm of Total Asset \\
\hline $\begin{array}{l}\text { Capital } \quad \text { Structure } \\
\text { (DAR) }\end{array}$ & $\begin{array}{l}\text { A measure (proportion) of the use of total } \\
\text { debt to finance all company investments or } \\
\text { capital }\end{array}$ & $\mathrm{DAR}=\frac{\text { Total debt }}{\text { Total asset }}$ \\
\hline Profitability (ROA) & $\begin{array}{l}\text { A measure of the rate of return } \\
\text { (return) on all equity owned by the } \\
\text { company. }\end{array}$ & $\mathrm{ROA}=\frac{\text { Profit after tax }}{\text { Total asset }}$ \\
\hline Tax & $\begin{array}{l}\text { Income tax is a tax imposed on profits } \\
\text { earned by the company. }\end{array}$ & Tax $=\frac{\text { Annual Depreciation }}{\text { Total asset }}$ \\
\hline
\end{tabular}

\section{Empirical Model}

The research design is illustrated in Figure 1.

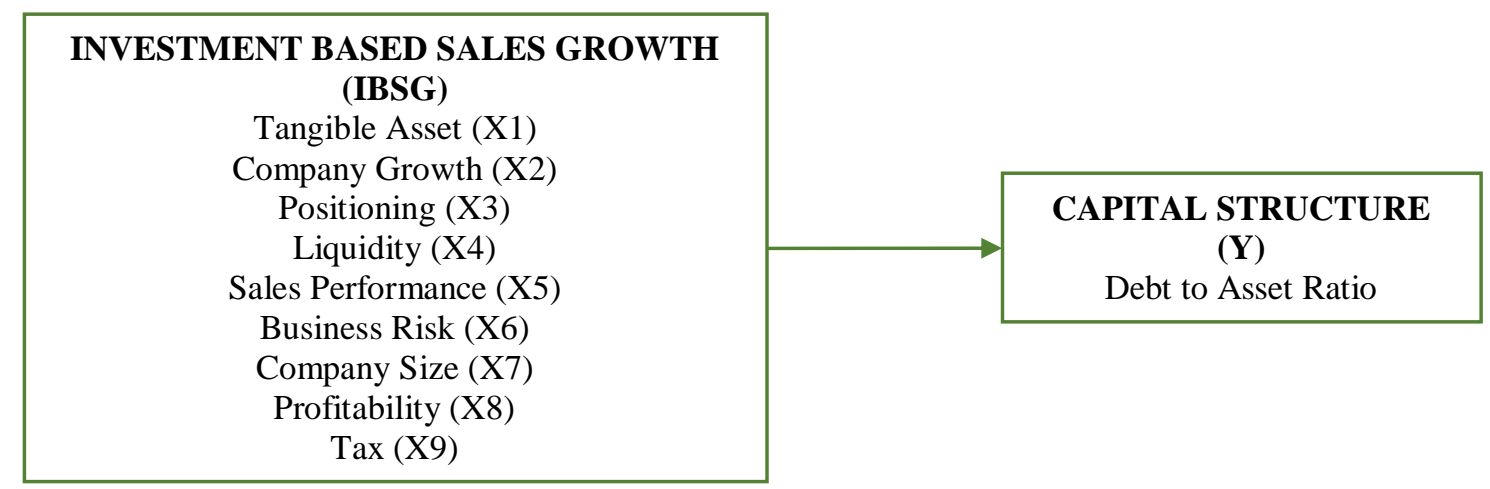

Figure 1. Research Design

The multiple regression equation in this study is:

$Y=\alpha+\beta_{1} X_{1}+\beta_{2} X_{2}+\beta_{3} X_{3}+\beta_{4} X_{4}+\beta_{5} X_{5}+\beta_{6} X_{6}+\beta_{7} X_{7}+\beta_{8} X_{8}+\beta_{9} X_{9}+\varepsilon$

where, $\alpha$ is a constant while $\beta_{1}, \beta_{2}, \beta_{3}, \beta_{4}, \beta_{5}, \beta_{6}, \beta_{7}, \beta_{8}$, and $\beta_{9}$ are variable coefficients of tangible asset, company's growth, positioning, liquidity, sales performance, business risk, firm size, Profitability (ROA), and tax. 
The equation above is a multiple regression model of several independent variables and one dependent variable. Multiple linear regression model estimation aims to predict the parameters of the regression model, namely the constant value $(\alpha)$ and the regression coefficient $(\beta i)$.

\section{Data Analysis Technique}

The analysis technique used in this study was regression data with SPSS 21 software. In data processing, data tabulation using Excel to avoid calculation errors and make it easy to enter data into SPSS 21 for analysis. The analysis passed included normality test, classic assumption test consisting of multicollinearity, autocorrelation, and heteroscedasticity, multiple linear regression analysis, and finally hypothesis testing.

\section{FINDING}

\section{Descriptive Statistics}

Table 2. Descriptive Statistics

\begin{tabular}{lccccc}
\hline \multicolumn{1}{c}{ Variables } & $\mathrm{N}$ & Minimum & Maximum & Mean & Std. Deviation \\
\hline Tangible Asset & 63 & 0.0591 & 0.9907 & 0.419571 & 0.2176684 \\
Company's Growth & 63 & -0.1686 & 0.3521 & 0.077024 & 0.1062448 \\
Positioning & 63 & 0.1010 & 0.4280 & 0.219714 & 0.1000934 \\
Liquidity & 63 & 73 & 343 & 150.538571 & 50.0561649 \\
Sales Performance & 63 & -554650 & 2392082 & 123738.11 & 389996.5228 \\
Business Risk & 63 & -137887 & 160162 & 20285.603175 & 40022.1869 \\
Firm Size & 63 & 4.0243 & 7.5878 & 6.085050 & 0.8092943 \\
Profitability & 63 & -8.2200 & 22.2900 & 6.687937 & 7.6213592 \\
Tax & 63 & 0.0305 & 0.4806 & 0.242702 & 0.1070340 \\
Capital Structure & 63 & 0.3300 & 1.99 & 1.480460 & 0.3622382 \\
Source: SPSS, processed (2020) & & & & &
\end{tabular}

Based on the results of the table above, the independent variable of tangible assets was 63 samples. The mean or average value was 0.419571 . The maximum value was 0.9907 in 2017 by PT. Inti Agri Resources Tbk. The minimum value of 0.0591 in 2018 by PT. Delta Djakarta Tbk. The standard deviation was 0.2176684 , which means that the maximum increase in the mean of tangible assets variable was +0.2176684 , while the maximum decrease of the average tangible asset variable was 0.2176684 .

The independent variable of the company's growth was 63 samples. The mean or average value was 0.077024 . The maximum value was 0.3521 in 2018 by PT. Sariguna Primatirta Tbk. The minimum value of -0.1686 in 2018 by PT. Inti Agri Resources Tbk. The standard deviation was 0.1062448 , which meant that the maximum increase in the average growth variable of the company was +0.1062448 , while the maximum decrease of the average company's growth variable was -0.1062448 .

Positioning independent variables totalling 63 samples. The mean or average value was 0.219714 . The maximum value was 0.4280 in 2017 by PT. Indofood Sukses Makmur Tbk. The minimum value of 0.1010 in 2018 by PT. Prima Cakrawala Abadi Tbk. The standard deviation was 0.01000934, which means that the maximum increase in the average positioning variable was +0.01000934 , while the maximum decrease of the average positioning variable was -0.01000934 .

The liquidity independent variable had 63 samples. The mean or average value was $150.53 \%$. The maximum value of $343 \%$ in 2017 by PT. Mayora Indah Tbk. The minimum value of $73 \%$ in 2017 by PT. Multi Bintang Indonesia Tbk. The standard deviation was $50.05 \%$, which means that the maximum increase in the average liquidity variable was $+50.05 \%$, while the maximum decrease of the average liquidity variable is $-50.05 \%$.

The independent variable of sales performance was 63 samples. The mean or average value was IDR 123,738.11 (in million Rupiah). The maximum value is IDR 2,392,082 (in million Rupiah) in 2017 by 
PT. Mayora Indah Tbk. The minimum value of -Rp554,650 (in million Rupiah) in 2019 by PT. Mayora Indah Tbk Tbk. The standard deviation was IDR 389,996.52 (in million Rupiah), which meant that the maximum increase in the average sales performance variable was + IDR 389,996.52 (in million Rupiah), while the maximum decrease in the average sales performance variable was IDR 389. 996.52 (in million Rupiah).

The business risk independent variable had 63 samples. The mean or average value was IDR 20,285.60 (in million Rupiah). The maximum value was IDR 160,162 (in million Rupiah) in 2019 by PT. Nippon Indosari Corpindo Tbk. The minimum value of -Rp137,887 (in million Rupiah) in 2019 by PT. Tunas Baru Lampung Tbk. The standard deviation was IDR 40,022.18 (in million Rupiah), which meant that the maximum increase in the average business risk variable was + IDR 40,022.18 (in million Rupiah) while the maximum decrease from the average business risk variable was IDR 40 . 022.18 (in million Rupiah).

The independent variable firm size was 63 samples. The mean or average value is 6.085050 . The maximum value was 7,5878 in 2019 by PT. Indofood CBP Sukses Makmur Tbk. The minimum value of 4.0243 in 2019 by PT. Campina Ice Cream Industry Tbk. The standard deviation is 0.8092943, which means that the maximum increase in the average firm size variable is +0.8092943 , while the maximum decrease of the average firm size variable is -0.8092943 .

The independent variable of profitability was 63 samples. The mean or average value was $6.68 \%$. The maximum value was $22.29 \%$ in 2019 by PT. Delta Djakarta Tbk. The minimum value of $-8.22 \%$ in 2017 by PT. Prima Cakrawala Abadi Tbk. The standard deviation was $7.62 \%$, which means that the maximum increase in the average profitability variable was $+7.62 \%$, while the maximum decrease from the average profitability variable was $-7.62 \%$.

Tax independent variables amounted to 63 samples. The mean or average value was 0.242702 . The maximum value of 0.4806 in 2017 by PT. Siantar Top Tbk. The minimum value of 0.0305 in 2018 by PT. Bumi Teknokultura Unggul Tbk. The standard deviation was 0.1070340, which means that the maximum increase in the average tax variable was +0.1070340 , while the maximum decrease of the average tax variable was -0.1070340 .

The dependent variable of capital structure which was proxied by DAR is 63 samples. The mean or average value was $1.48 \%$. The maximum value of $1.99 \%$ in 2017 by PT. Akasha Wira International Tbk. The minimum value of $0.33 \%$ in 2018 by PT. Prima Cakrawala Abadi Tbk. The standard deviation was $0.362 \%$, which means that the maximum increase in the average capital structure variable was $+0.362 \%$, while the maximum decrease of the average capital structure variable was $0.362 \%$.

\section{Classic Assumption Test Results}

Before performing regression analysis, first to test the classical assumption of residual normality test, multicollinearity test, autocorrelation, and heteroscedasticity test.

Table 3. Normality Test

\begin{tabular}{llc}
\hline One-Sample Kolmogorov-Smirnov Test & Unstandardized Residual \\
\hline $\mathrm{N}$ & & 63 \\
Normal Parameters & Mean & 0.0000000 \\
& Std. Deviation & 0.23796020 \\
Most Extreme Differences & Absolute & 0.065 \\
& Positive & 0.060 \\
Kolmogorov-Smirnov $\mathrm{Z}$ & Negative & -0.065 \\
Asymp. Sig. (2-tailed) & & 0.515 \\
\hline
\end{tabular}

Source: SPSS, processed (2020)

If the sig value> 0.05 , it can be concluded that the data was normally distributed. In the table above, the value of sig $=0.954$ is greater than 0.05 (data is normally distributed). 
Table 4. Multicollinearity Test Result

\begin{tabular}{lcc}
\hline \multirow{2}{*}{\multicolumn{1}{c}{ Variables }} & \multicolumn{2}{c}{ Collinearity Statistics } \\
\cline { 2 - 3 } & Tolerance & VIF \\
\hline Tangible Asset & 0.757 & 1.321 \\
Company's Growth & 0.829 & 1.207 \\
Positioning & 0.947 & 1.056 \\
Liquidity & 0.836 & 1.196 \\
Sales Performance & 0.731 & 1.367 \\
Business Risk & 0.916 & 1.092 \\
Firm Size & 0.879 & 1.138 \\
Profitability & 0.797 & 1.255 \\
Tax & 0.873 & 1.146 \\
\hline
\end{tabular}

Source: SPSS, processed (2020)

The VIF value of tangible assets $\left(\mathrm{X}_{1}\right)$ was obtained at 1.321 . The VIF value of the company growth $\left(\mathrm{X}_{2}\right)$ was obtained at 1.207. The VIF value of the positioning $\left(\mathrm{X}_{3}\right)$ was 1.056 . The VIF value of liquidity $\left(\mathrm{X}_{4}\right)$ was obtained at 1.196 . The VIF value of the sales performance $\left(\mathrm{X}_{5}\right)$ was 1.367. The VIF value of business risk $\left(\mathrm{X}_{6}\right)$ is 1.092 . The VIF value of the company size $\left(\mathrm{X}_{7}\right)$ was obtained at 1.138. The VIF value of profitability $\left(\mathrm{X}_{8}\right)$ is 1.255 . The VIF value of tax $\left(\mathrm{X}_{9}\right)$ was obtained at 1.146. Based on the multicollinearity test results above the VIF value of the nine independent variables, which were still between 1-10, it can be concluded that there was no multicollinearity.

Table 5. Autocorrelation Test Result

\begin{tabular}{lccccc}
\hline Model & $\mathrm{R}$ & R Square & Adjusted R Square & $\begin{array}{c}\text { Std. The error of the } \\
\text { Estimate }\end{array}$ & Durbin-Watson \\
\hline 1 & $0.754^{\mathrm{a}}$ & 0.568 & 0.495 & 0.2573726 & 1.989 \\
\hline Source: SPSS, processed (2020) & &
\end{tabular}

The Durbin Watson table value can be seen in the Durbin Watson table (k, n) so (9.63) (k is the value of the number of independent variables) the $\mathrm{dl}$ and du values are obtained, so the $\mathrm{dl}$ and du values were 1.285 and 1.926 . Then the autocorrelation value was $1.926<1.989<2.074$ so there was no autocorrelation.

Table 6. Heteroscedasticity Test Result

\begin{tabular}{lcc}
\hline \multicolumn{1}{c}{ Variables } & $\mathrm{t}$ & Significance \\
\hline (Constant) & -0.639 & 0.526 \\
Tangible Asset & -0.330 & 0.742 \\
Company's Growth & 0.029 & 0.977 \\
Positioning & 0.925 & 0.359 \\
Liquidity & 1.086 & 0.282 \\
Sales Performance & -0.380 & 0.706 \\
Business Risk & -0.420 & 0.676 \\
Firm Size & 0.734 & 0.466 \\
Profitability & -0.536 & 0.594 \\
Tax & 2.492 & 0.116 \\
\hline a. Dependent Variable: abs_res & & \\
Source: SPSS, processed (2020) &
\end{tabular}

By using the Glejser test by regressing the residual absolute value on the independent variable (Ghozali, 2011). The results can be said that the variable $X_{1}$ (tangible assets) has a significance value of $0.742>0.05$. The variable $X_{2}$ (company growth) has a significance value of $0.977>0.05$. The variable $\mathrm{X}_{3}$ (positioning) has a significance value of $0.359>0.05$. The variable $\mathrm{X}_{4}$ (liquidity) has a significance value of $0.282>0.05$. The variable $\mathrm{X}_{5}$ (sales performance) has a significance value of $0.706>0.05$. The variable $X_{6}$ (business risk) has a significance value of $0.676>0.05$. The variable $X_{7}$ (company size) has a significance value of $0.466>0.05$. The variable $\mathrm{X}_{8}$ (profitability) has a 
significance value of $0.594>0.05$. The variable $X_{9}(\operatorname{tax})$ has a significance value of $0.116>0.05$. The nine independent variables have a significance value of more than $0.05(\alpha>0.05)$, so it can be concluded that the regression model does not have heteroscedasticity problem.

\section{Hypothesis Testing}

\section{Multiple Linear Regression Analysis}

Table 7. Multiple Linear Regression Result

\begin{tabular}{lccc}
\hline \multicolumn{1}{c}{ Variables } & Coefficients & $\mathrm{t}$ & Significance \\
\hline (Constant) & -0.119 & -0.392 & 0.696 \\
Tangible Asset & 0.903 & 5.230 & 0.000 \\
Company's Growth & -0.853 & -2.525 & 0.015 \\
Positioning & 0.984 & 2.933 & 0.005 \\
Liquidity & 0.002 & 2.213 & 0.031 \\
Sales Performance & -0.00000013 & -0.012 & 0.991 \\
Business Risk & 0.0000088 & 1.032 & 0.307 \\
Firm Size & 0.089 & 2.055 & 0.045 \\
Profitability & 0.017 & 3.628 & 0.001 \\
Tax & 0.657 & 2.010 & 0.049 \\
\hline Saur
\end{tabular}

Source: SPSS, processed (2020)

Based on the table above, the results of the multiple linear regression equation can be explained as follows.

$$
\begin{aligned}
\mathrm{Y} & =-0.119+0.903 \mathrm{X}_{1}-0.853 \mathrm{X}_{2}+0.984 \mathrm{X}_{3}+0.002 \mathrm{X}_{4}+0.00000013 \mathrm{X}_{5}+0.0000088 \mathrm{X}_{6}+0.089 \mathrm{X}_{7} \\
& +0.017 \mathrm{X}_{8}+0.657 \mathrm{X}_{9}+\varepsilon
\end{aligned}
$$

Based on the multiple linear regression equation above, it shown that the positioning variable was the most dominant variable in influencing the capital structure of 0.984 . This was because the value of the regression coefficient for this variable was the highest, followed by tangible assets, taxes, firm size, profitability, liquidity, business risk, sales performance, and company's growth.

\section{T-statistic Test}

The $t$ value of the tangible asset variable above was 5,230 with a significance value of 0,000 or less than 0.05. Therefore Ho was accepted and $\mathrm{Ha}$ was rejected. It can be stated that tangible assets positively influenced and significant to the capital structure of food and beverages companies.

The $t$ value of the company's growth variable was -2.525 with a significance value of 0.015 or less than 0.05 . Therefore Ho was accepted and Ha was rejected. Then this can be said that company's growth negatively influenced and significant to the capital structure of food and beverages companies.

The $t$ value of the positioning variable was 2.933 with value of significance was 0.005 or less than 0.05. Therefore Ho was accepted and $\mathrm{Ha}$ was rejected. This also can be stated that positioning positively influenced and significant to the capital structure of food and beverages companies.

The $t$ value for the liquidity variable was 2.213 with value of significance was 0.031 or less than 0.05 . Therefore Ho was accepted and $\mathrm{Ha}$ was rejected. So it can be concluded that liquidity positively influenced and significant to the capital structure of food and beverages companies.

The $t$ value for the sales performance variable was -0.012 with a significance value of 0.991 or more than 0.05 . Therefore Ho was rejected and Ha was accepted or can be stated that capital structure is not influenced by sales performance.

Capital structure is not influenced by business risk because the $t$ value for the business risk variable was 1.032 with a significance value of 0.307 or more than 0.05 . Therefore Ho was rejected and $\mathrm{Ha}$ is accepted. 
There was significant and positively influenced of firm size to the capital structure of food and beverages companies because the $\mathrm{t}$ value for the firm size variable was 2.055 with a significance value of 0.045 or less than 0.05 . Therefore Ho was accepted and Ha was rejected.

According to the table above, the $t$ value for the profitability variable was 3.628 with a significance value of 0.001 or less than 0.05 . Therefore Ho was accepted and Ha was rejected. This meant that it can be stated that profitability positively influenced and significant to the capital structure of food and beverages companies.

By looking at the table result above, the $t$ value for the tax variable was 2.010 with a significance value of 0.049 or less than 0.05 . Therefore Ho was accepted and Ha was rejected. This meant that it can be stated that tax positively influenced and significant to the capital structure of food and beverages companies.

\section{The Coefficient of Determination $\left(\mathbf{R}^{2}\right)$ Test}

This test measures how far the model's ability in explaining the effect of the independent variable to the dependent variable. The coefficient of determination is between zero and one.

Table 8. R Square Test Result

\begin{tabular}{lcccc}
\hline Model & $\mathrm{R}$ & R Square & Adjusted R Square & $\begin{array}{c}\text { Std. The error of the } \\
\text { Estimate }\end{array}$ \\
\hline 1 & $0.754^{\mathrm{a}}$ & 0.568 & 0.495 & 0.2573726 \\
\hline Source: SPSS, processed (2020) & & &
\end{tabular}

The value of $\mathrm{R}$ square or the coefficient of determination was 0.568 , it would be better to use adjusted $\mathrm{R}$ Square if the number of independent variables were more than two. So the adjusted $\mathrm{R}$ square value is 0.495 . This implied that $49.5 \%$ of the capital structure variation might be explained by the variation of these nine independent variables. Meanwhile, the remaining 50.5\% (100\% - 49.5\%) was explained by other reasons, such as the effect of ownership control, sales stability, asset structure, operating leverage, and so on.

\section{F-statistic test}

The $\mathrm{F}$ test is implmented to see the goodness of fit or the feasibility of regression model, whether the model conducted in the research is fit or not. The model would be concluded to be fit if the significance value was less than 0.05 . The test results are shown in the following table.

Table 9. F-statistic Test Result

\begin{tabular}{llccccc}
\hline & Model & Sum of Squares & df & Mean Square & F & Sig. \\
\hline & Regression & 4.625 & 9 & .514 & 7.757 & $.000^{\mathrm{b}}$ \\
\cline { 2 - 5 } & Residual & 3.511 & 53 & .066 & & \\
& Total & 8.135 & 62 & & & \\
\hline
\end{tabular}

Source: SPSS, processed (2020)

The F test is basically as same as the coefficient of determination test which is also conducted to assess the goodness of the model. The table above F counts for 7.757 with a significance level of 0.000 less than 0.05 . Then the model might be implemented.

\section{DISCUSSION}

\section{Relationship of Tangible Assets to Capital Structure}

$\mathrm{H}_{1}$ was accepted that tangible assets positively influenced and significant to the capital structure of food and beverages companies. This statement agreed with previous studies that have been done by (Akinyomi \& A. Olagonju, 2013; Ichwan, 2015; Tijow et al., 2018). This result is accepted because the tangible assets in this study compared the company's tangible assets with total assets which illustrates the amount of assets that the company can guarantee when making loans to creditors. By considering at the trade-off theory, tangible assets positively influenced and significant to the capital structure of food and beverages companies. The more assets of a company, the more of collateral 
assets are able to get external funding by getting debt. The greater of the tangible assets, the higher of the company's capital structure from debt.

\section{Relationship of Company's Growth to Capital Structure}

$\mathrm{H}_{2}$ was accepted that company's growth negatively influenced and significant to the capital structure of food and beverages companies. This statement agreed with previous studies that have been done by (Alipour et al., 2015; Chadha \& Sharma, 2015; Saleem et al., 2013; Sari, 2015). $\mathrm{H}_{2}$ was accepted because the results reflected that if the company's growth rate increased, the capital structure of the company would decreased. Companies with high growth prefer to optimilize their own capital or retained earnings to fulfill their funding rather than using long-term debt. So that in fulfilling funding needs, companies that experience increased sales do not always take funds from debt but use their own capital or retained earnings.

\section{Relationship of Positioning to Capital Structure}

$\mathrm{H}_{3}$ was accepted that positioning positively influenced and significant to the capital structure of food and beverages companies. This statement agreed with previous studies that have been done by (Akinyomi \& A. Olagonju, 2013; Ichwan, 2015; Tijow et al., 2018). $\mathrm{H}_{3}$ can be accepted because the positioning in this study explained how high the company's sales growth position compared to industrial sales growth. The higher of the company's sales growth position in similar industrial group, the easier opportunity of the company to fulfil external capital or come from long-term debt, this make the company's capital structure higher.

\section{Relationship of Liquidity to Capital Structure}

The liquidity variable positively influenced and significant to the capital structure of food and beverages companies on the Indonesia Stock Exchange for the 2017-2019 period. This statement agreed with previous studies that have been done by (Joni \& Lina, 2010; Sabir \& Qaisar, 2012; Sakti, 2002) which stated that liquidity positively influenced and significant to the capital structure where the higher of the liquidity of a company, the higher of the company's ability to pay its short-term debt. This happened because developing companies generally require large funds. If internal funds are not sufficient for the company's needs, the company will choose debt as its external funding source. If internal funds are not sufficient for the company's needs, the company chooses debt as its external funding source.

\section{Relationship of Sales Performance to Capital Structure}

An increase in the company's sales performance will have an effect on improving the capital structure, for companies with a high level of sales performance, the tendency to use debt is greater than companies with low growth rates. However, the results of this study were not in accordance with the above statement. The results show that capital structure is not influenced by sales performance and this statement agreed with previous studies that have been done by (Athifah, 2014; Maryanti, 2016; Widayanti, Luh Putu. Triaryati \& Abundanti, 2016). capital structure is not influenced by sales performance because companies with high sales growth prefer to take their own capital or retained earnings in fulfilling their funding needs rather than using long-term debt. So that in this result explained companies that experience increased sales do not always take funds from debt but rather use their own capital or retained earnings.

\section{Relationship of Business Risk to Capital Structure}

Capital structure is not influenced by business risk because the low risk will result in company management not considering business risk in determining the amount of debt. The same research results were obtained by (Ahmad, Abdullah, \& Roslan, 2012; Indrajaya, 2012; Kartika, 2016) which stated that capital structure is not influenced by business risk. If the income is high, the company's business risk will be high so that the profit generated tends to fluctuate, which means that income is unstable, with high business risk the company tends not to reduce debt, but still uses debt to meet its funding needs. This study supports the trade-off theory, in which companies that have high 
profitability and at the same time will have high business risks will try to reduce their taxes by increasing their debt ratios so that the additional debt will reduce taxes. In addition, the results of this study are also strengthened by the pecking order theory that the company will prioritize internal funding sources, so that when the company gets a large profit, external financing will decrease.

\section{Relationship of Firm Size to Capital Structure}

Large companies will be easier to obtain capital in the capital market compared to small companies because this easy access means that large companies have greater flexibility because companies with larger size have greater confidence in obtaining sources of funds so that it will be easier to obtain them. credit from outside parties. Therefore, large company size is a positive signal for creditors to provide loans. So that firm positively influenced and significant to the capital structure of food and beverages companies. The size of a company will affect the capital structure, the larger the company, the greater the funds needed by the company to make investments. The larger the size of a company, the greater the tendency to use external capital. This is because large companies also need large funds to support their operations, and one alternative to fulfill external capital if their own capital is insufficient. The results of this study agreed with previous studies that have been done by (Abdul, 2007; Ariyanto, 2002; Armelia, 2016; Handayani, 2011) which stated that positively influenced and significant to the capital structure.

\section{Relationship of Profitability to Capital Structure}

Profitability which was proxied by (ROA) positively influenced and significant to the capital structure of food and beverages companies. The result of this study indicated that profitability that any increase in profitability will always be followed by an increase in capital structure. The higher of the company's profitability, the greater of the retained earnings but it would be balanced with higher debt because the company's prospects are better considered. Profitability positively influenced to the capital structure, which can occur because companies that are expanding require a lot of funds to encourage an increase of the profits in the future. This result is in accordance with the trade-off the theory that companies that earn large amounts of profit will use them as a source of external funding to benefit from tax savings. The results of this study agreed with previous studies that have been done by (Dewi \& Sudiartha, 2017; Handayani, 2011; Puspawardhani, 2011) which stated that profitability positively influenced and significant to the capital structure of food and beverages companies.

\section{Relationship of Tax to Capital Structure}

High tax rates make companies tend to prefer debt, because with debt, the amount of tax that the company must pay will be reduced. According to the trade-off theory, a company that has a high debt ratio makes the amount of money it must spend to pay its debt and interest. The statement indicates that high debt will be able to reduce the level of income and its tax, therefore the company will pay lower income taxes. This statement agreed with previous studies that have been done by (Andelina, 2015; Widati \& Nafisah, 2017) which stated that tax positively influenced and significant to the capital structure.

\section{CONCLUSION}

The conclusion of this research must be emphasized that Tangible assets positively influenced to the capital structure, The growth of the company resulted negatively influenced to the capital structure, positioning positively influenced to the capital structure, liquidity positively significant influenced to the capital structure, capital structure is not influenced by sales performance and business risk, firm size positively influenced to the capital structure, profitability positively significant influenced to the capital structure, tax positively significant influenced to the capital structure.

\section{Limitation and Recommendation}

The first limitation is that the resulting adjusted $\mathrm{R}$ square value is low because it is only 49.5. This implied that $49.5 \%$ of the capital structure variation might be explained by the variation of these nine 
independent variables. Meanwhile, the remaining 50.5\% (100\% - 49.5\%) was explained by other reasons, such as the effect of ownership control, sales stability, asset structure, operating leverage, and so on. Suggestion for further researchers is to add other variables that can affect the capital structure such as the effect of ownership control, sales stability, asset structure, operating leverage, and so on.

The second limitation is that the number of company samples is too small because the research period is only 3 years starting from 2017 to 2019 so that when the population is selected, the sample is selected using purposive sampling, a large number of samples are selected because they do not meet the existing criteria. Suggestion for future research is to increase the period of research, in order to increase the number of existing data samples.

\section{Managerial Implications}

This analysis tool can be used as an indicator for measuring the banking sector in giving loans to MSME customers, where this tool can also strengthen the 5C (Character, Capacity, Capital, Condition, Collateral) analysis tool in banking. It is hoped that the implication of this analysis tool in banking can help banking activities in preventing defaults which will increase the bank's NPL figure as a form of moral hazard behavior of customers who make loans to banks.

\section{REFERENCES}

Abdul, H. (2007). Manajemen Keuangan Bisnis. Bogor: Penerbit Ghalia Indonesia.

Ahmad, Z., Abdullah, N. H., \& Roslan, S. (2012). Capital Structure Effect on Firms Performance: Focusing on Consumers and Industrials Sectors on Malaysian Firms. International of Business Research, $137-155$. http://citeseerx.ist.psu.edu/viewdoc/download?doi=10.1.1.458.8815\&rep=rep1\&type=pdf

Akinyomi, O. J., \& A. Olagonju. (2013). Determinants of Capital Structure in Nigeria. International Journal of Innovation and Applied Studies, 3(4), 999-1005. http://www.ijias.issrjournals.org/abstract.php?article=IJIAS-13-148-05

Al-Najjar, B., \& Hussainey, K. (2011). Revisiting The Capital-Structure Puzzle: UK Evidence. The Journal of Risk Finance, 12(4), 329-338. http://doi.org/10.1108/15265941111158505

Alipour, M., Mohammadi, M. F., \& Seddigh Hojjatollah, D. (2015). Determinants of Capital Structure: An Empirical Study of Firms in Iran. International Journal of Law and Management, 57(1), 53-83. http://dx.doi.org/10.1108/IJLMA-01-2013-0004

Allen, F. (2000). Capital Structure and Imperfect Competition in Product Markets. Incentives, Organization, and Public Economics: Papers in Honor of Sir James Mirrlees, 281. https://econpapers.repec.org/paper/fthpennfi/11-87.htm

Andelina, M. W. (2015). Pengaruh Profitabilitas, Perubahan Pajak, Pertumbuhan Perusahaan dan Ukuran Perusahaan terhadap Keputusan Pendanaan pada Perusahaan Manufaktur yang Terdaftar di Bursa Efek Indonesia. Jurnal Universitas Stikubank Semarang. https://www.unisbank.ac.id/ojs/index.php/fe8/article/view/2930

Ariyanto. (2002). Pengaruh Struktur Pemegang Saham Terhadap Struktur Modal Perusahaan. Jurnal Manajemen Indonesia, 1(1).

Armelia, S. (2016). Pengaruh Ukuran Perusahaan, Profitabilitas, Likuiditas dan Struktur Aktifa terhadap Struktur Modal Perusahaan Manufaktur Go Publik (Studi Sektor Kosmetik Dan $\begin{array}{llllll}\text { Keperluan } & \text { Rumah } & \text { Tangga). } & \text { JOM } & \text { FISIP, } & 3(2),\end{array}$ https://jom.unri.ac.id/index.php/JOMFSIP/article/view/11250

Athifah, H. (2014). Pengaruh Pertumbuhan Penjualan, Profitabilitas, Struktur Aktiva dan Ukuran Perusahaan Terhadap Struktur Modal (Studi Pada Perusahaan Property dan Real Estate yang Terdaftar di Bursa Efek Indonesia). Jurnal Manajemen. Fakultas Ekonomi Dan Bisnis Universitas Brawijaya, 1(10), 7-9.

Baker, H. K., \& Powell, G. (2009). Understanding Financial Management: A Practical Guide. Wiley.

Booth, L., Aivazian, V., Demirguc-Kunt, A., \& Maksimovic, V. (2001). Capital Structures in Developing Countries. The Journal of Finance, 56(1), 87-130. http://doi.org/10.1111/0022$\underline{1082.00320}$ 
Caballero, B., García-Teruel, P., \& Solano, P. (2012). How Does Working Effect The Profitability of Spanish SMEs. Small Business Economics, 39(1), 517-529. http://doi.org/10.1007/s11187-0119317-8

Chadha, S., \& Sharma, A. K. (2015). Determinants of Capital Structure: An Empirical Evaluation from India. Journal of Advances in Management Research, 12(1), 3-14. http://doi.org/10.1108/JAMR-08-2014-0051

DeAngelo, H., \& Masulis, R. W. (1980). Optimal Capital Structure Under Corporate and Personal Taxation. Journal of Financial Economics, 8(1), 3-29. https://doi.org/10.1016/0304$\underline{405 X(80) 90019-7}$

Deloof, M. (2003). Does Working Capital Management Affect Profitability of Belgian Firms? Journal of Business Finance \& Accounting, 30(4), 573-588. http://doi.org/10.1111/1468-5957.00008

Dewi, D. ., \& Sudiartha, G. . (2017). Pengaruh Profitabilitas, Ukuran Perusahaan, dan Pertumbuhan Aset Terhadap Struktur Modal dan Nilai Perusahaan. E-Jurnal Manajemen Unud, 6(4), 222222252. https://ojs.unud.ac.id/index.php/Manajemen/article/download/28486/18237

Ding, S., \& Guariglia., A. (2013). Investment and Financing Constraints In China: Does Working Capital Management Make A Difference?. Journal of Banking \& Finance, 37(5), 1490-1507. https://doi.org/10.1016/j.jbankfin.2012.03.025

Enqvist, J., Graham, M., \& Nikkinen, J. (2014). The Impact Of Working Capital Management On Firm Profitability in Different Business Cycles: Evidence From Finland. Research in International Business and Finance, Elsevier, 32(c), 36-49. https://doi.org/10.1016/j.ribaf.2014.03.005

Garcia-Teruel, P., \& Solano, P. (2007). Effects of Working Capital Management on SME Profitability. International Journal of Managerial Finance, 3(2), 164-177. https://doi.org/10.1108/17439130710738718

Ghozali, I. (2011). Aplikasi Analisis Multivariate Dengan Program SPSS (Kelima). Semarang: Badan Penerbit Universitas Diponegoro.

Gill, A., Bigger, N., \& Mathur, N. (2010). The Relationship Between Working Capital Management and Profitability: Evidence From The United States. Business and Economic Journal. https://astonjournals.com/manuscripts/Vol2010/BEJ-10 Vol2010.pdf

Graham, J. R., \& Harvey, C. R. (2001). The Theory and Practice of Corporate Finance: Evidence From The Field. Journal of Financial Economics, 60(2), 187-243. https://doi.org/10.1016/S0304-405X(01)00044-7

Handayani, S. (2011). Analisis Faktor yang Mempengaruhi Struktur Modal Serta Pengaruhnya Terhadap Harga Saham Perusahaan Real Estate yang Go Public di Bursa Efek Indonesia. Jurnal Bisnis Dan Akuntansi, 13(1), 39-56.

Harris, M., \& Raviv, A. (1991). The Theory of Capital Structure. The Journal of Finance, 46(1), 297355. https://doi.org/10.1111/j.1540-6261.1991.tb03753.x

Ichwan. (2015). Pengaruh Ukuran Perusahaan, Struktur Aktiva dan Profitabilitas Terhadap Struktur Modal. Jurnal Ilmu \& Riset Akuntansi, 4(6), 1-19.

Indrajaya, G. (2012). Pengaruh Struktur Aktiva, Ukuran Perusahaan, Tingkat Pertumbuhan, Profitabilitas dan Risiko Bisnis Terhadap Struktur Modal (Studi Empiris Pada Perusahaan Sektor Pertambangan yang Listing di Bursa Efek Indonesia Periode 2004-2007). Akurat Jurnal Ilmiah Akuntansi, 6(2). https://media.neliti.com/media/publications/220275-pengaruh-struktur-aktivaukuran-perusaha.pdf

Jensen, M. C., \& Meckling, W. H. (1976). Theory of The Firm: Managerial Behavior, Agency Costs and Ownership Structure. Journal of Financial Economics, 3(4), 305-360. https://doi.org/10.1016/0304-405X(76)90026-X

Joni, \& Lina. (2010). Faktor-faktor yang Mempengaruhi Struktur Modal. Jurnal Bisnis Dan Akuntans, $12(2), 81-96$.

Kartika, A. (2016). Pengaruh Profitabilitas, Struktur Aset, Pertumbuhan Penjualan dan Ukuran Perusahaan terhadap Struktur Modal Perusahaan Manufaktur Di Bursa Efek Indonesia. INFOKAM, 1(12). http://amikjtc.com/jurnal/index.php/jurnal/article/view/99

Lazaridis, \& Tryfonidis. (2006). Relationship Between Working Capital Management and Profitability of Listed Companies in The Athens Stock Exchange. Journal of Financial Management and 
Analysis, 19(1), 26-25. http://dx.doi.org/10.5539/ijbm.v7n1p58

Maryanti. (2016). Analisis Profitabilitas, Pertumbuhan Perusahaan, Pertumbuhan Penjualan dan Struktur Aktiva terhadap Struktur Modal Pada Perusahaan Sektor Industri Barang Konsumsi yang Terdaftar Di Bursa Efek Indonesia. Riset Akuntansi Dan Keuangan Indonesia, 1(2), 143151. http://journals.ums.ac.id/index.php/reaksi/article/view/2730

Memon, P. A., Rus, R. B. M., \& Ghazali, Z. B. (2015). Firm and Macroeconomic Determinants of Debt: Pakistan Evidence. Procedia-Social and Behavioral Sciences, 172, 200-207. https://doi.org/10.1016/j.sbspro.2015.01.355

Modigliani, F., \& Miller, H. (1958). The Cost of Capital, Corporate Finance and Theory of Investment. American Economic Review. http://doi.org/10.1080/17446540802345448

Myers, S. C., \& Majluf, N. S. (1984). Corporate Financing and Investment Decision When Firm Have Information That Investor Do Not Have. Journal of Financial Economics, 13, 419-453. https://doi.org/10.1016/0304-405X(84)90023-0

Padachi, K. (2006). Trends in working capital management and its impact on firms' performance: An analysis of Mauritian small manufacturing firms. International Review of Business Research Papers, 2(2), https://citeseerx.ist.psu.edu/viewdoc/download?doi=10.1.1.475.2653\&rep=rep1\&type=pdf

Prabansari, Y., \& Hadri, K. (2005). Faktor-faktor yang Mempengaruhi Struktur Modal Pada Perusahaan Manufaktur Yang Terdaftar Di Bursa Efek Jakarta. Jurnal Sinergi Edisi Khusus On Finance, 1-15. https://doi.org/10.20885/js.v0i0.935

Puspawardhani, N. (2011). Pengaruh Pertumbuhan Penjualan, Profitabilitas, Struktur Aktiva dan Ukuran Perusahaan Terhadap Struktur Modal Pada Perusahaan Pariwisata dan Perhotelan di BEI. E-Jurnal Manajemen Unud, 6(4), 2212-2222. https://ojs.unud.ac.id/index.php/Manajemen/article/view/8284

Ruslim, H. (2009). Pengujian struktur modal (teori pecking order): analisis empiris terhadap saham di LQ-45. Jurnal Bisnis Dan Akuntansi, 11(3), 209-221. https://jurnaltsm.id/index.php/JBA/article/view/245

Sabir, M., \& Qaisar, A. M. (2012). Determinants of Capital Structure - A Study of Oil and Gas Sector of Pakistan. Interdisciplinary Journal Of Contemporary Research In Business, 3(10), 395-400. https://journal-archieves15.webs.com/395-400.pdf

Sakti, R. B. (2002). Pengaruh Struktur Aktiva, Ukuran Perusahaan,Operating Leverage, Profitabilitas, Likuiditas dan Pertumbuhan Penjualan terhadap Struktur Modal Pada Industri Dasar Dan Kimia Di BEJ. Tesis Magister Manajemen Universitas Gadjah Mada.

Saleem, F., Bisma Rafique, Q., Mehmood, M., Irfan, R. S., \& Sidra Tariq, G. A. (2013). The Determinant of Capital Structure of Oil and Gas Firms Listed on Karachi Stock Exchange In Pakistan. Interdisciplinary Journal of Contemporary Research In Business, 4(9), 225-235. https://journals.udsm.ac.tz/index.php/bmr/article/download/2840/2858

Sari, R. M. C. (2015). Faktor - Faktor yang Mempengaruhi Struktur Modal Perusahaan Manufaktur di BEI Tahun 2010-2012. Thesis Fakultas Ekonomi UNISSULA. http://repository.unissula.ac.id/527/

Scott, J. H. (1977). Bankruptcy, Secured Debt, and Optimal Capital Structure. The Journal of Finance, $32(1)$, $1-19$. https://econpapers.repec.org/article/blajfinan/v_3a32_3ay_3a1977_3ai_3a1_3ap_3a1-19.htm

Tijow, A. ., Sabijono, H., \& Tirayoh, V. . (2018). Pengaruh Struktur Aktiva dan Profitabilitas terhadap Struktur Modal Pada Perusahaan Sektor Industri Barang Konsumsi yang Terdaftar Di Bursa Efek Indonesia. Jurnal Riset Akuntansi Going Concern, 13(3), 477-488. https://ejournal.unsrat.ac.id/index.php/gc/article/view/20375

Titman, S., \& Wessels, R. (1988). The Determinants of Capital Structure Choice. The Journal of Finance, 43(1), 1-19. https://doi.org/10.1111/j.1540-6261.1988.tb02585.x

Widati, L. W., \& Nafisah, S. (2017). Analisis Pengaruh Struktur Aset, Risiko Bisnis, Pajak dan Likuiditas terhadap Keputusan Pendanaan Pada Perusahaan Manufaktur yang Terdaftar Di Bursa Efek Indonesia. Dinamika Akuntansi, Keuangan Dan Perbankan, 6(1), 19-27. https://www.unisbank.ac.id/ojs/index.php/fe9/article/view/5949

Widayanti, Luh Putu. Triaryati, N., \& Abundanti, N. (2016). Pengaruh Profitabilitas, Tingkat 
Pertumbuhan Perusahaan, Likuiditas, Dan Pajak Terhadap Struktur Modal Pada Sektor Pariwisata. E-Jurnal Manajemen Unud, 5(6), 3761-3793.

https://ojs.unud.ac.id/index.php/Manajemen/article/view/20967 